\title{
Field testing of immobilized oil-degrading microorganisms in the Zhanatalap field of Atyrau region
}

\author{
(C) Alibek A. Kaziev, ${ }^{1 *+}$ Amantay Sh. Akzhigitov, ${ }^{2}$ \\ Sofia Z. Sagyndykova, ${ }^{3}$ and Azamat N. Nurlybekov ${ }^{3}$ \\ ${ }^{1}$ Department of Applied Biology and Microbiology. Astrakhan State Technical University. Tatishchev \\ St.16. Astrakhan, 414056.Russia.Phone:+7 (8512)614-271.E-mail: alibek.kaziev.88@mail.ru \\ ${ }^{2}$ Atyrau State University of Oil and Gas Named after Safi Utebaev. Atyrau. \\ Republic of Kazakhstan.E-mail: aman.aing@rambler.ru \\ ${ }^{3}$ Atyrau State University Named after Khalel Dosmukhamedov. Atyrau. \\ Republic of Kazakhstan.E-mail: sofiazul@mail.ru
}

\begin{abstract}
${ }^{*}$ Leading directions; ${ }^{+}$Corresponding author
Keywords: immobilization, Voroshilova-Dianova nutrient medium, hydrocarbon-oxidizing microorganisms, zeolite, expanded clay.
\end{abstract}

\section{Abstract}

Hydrocarbon-oxidizing microorganisms are widespread in natural ecosystems, since the ability to oxidize hydrocarbons is associated with the presence of enzymes of the oxidase group, with microorganisms using oil and oil products as the sole source of carbon and energy in the microbiological decomposition of hydrocarbons. The decomposition of oil and oil products in the soil under natural conditions is a biogeochemical process in which the functional activity of a complex of soil microorganisms that ensure the complete mineralization of oil and oil products to carbon dioxide and water is of crucial importance. The search for effective indigenous hydrocarbon-oxidizing microorganisms, the creation on their basis of a fullfledged specialized consortium of microorganisms and their introduction into the initial, cleaned environment is one of the promising methods of purification with oil pollution in the oil-producing regions of Kazakhstan.

Among the new biological methods for cleaning soil from oil pollution, the most promising are the use of a consortium based on immobilized microorganisms.

A correctly selected carrier capable of sorption of petroleum hydrocarbons preserves and maintains attached cells in a viable state for a long time and protects them, especially at the initial stage of introduction, from adverse environmental conditions, which increases the efficiency of oil destruction. Hydrocarbonoxidizing microorganisms have high emulsifying activity and sorption ability for expanded clay, optimal conditions for biomass accumulation are: temperature $28-30^{\circ} \mathrm{C}, \mathrm{pH}=7$ and 9 .

It is recommended to use a consortium of oil-degrading microorganisms based on the native strains of cultures Bacillus firmus S20, Bacillus subtilis PR28, Micrococcus roseus UD6-4, Micrococcus varians PR69 to clean the soils contaminated with oil and oil products in the Zhanatalap field in the Atyrau region.

It should be noted that after 8 months at the Zhanatalap field in the Atyrau region, oil destruction amounted to $94.3 \%$ in the variant with the introduction of immobilized microorganisms on zeolite and expanded clay. The results of the research are the basis for further development of technology for the restoration of oil-contaminated soils in arid conditions of Kazakhstan.

\section{References}

[1] E.N. Kobzev, S.B. Petrikevich, A.N. Shkidchenko. Investigation of the stability of the association of microorganisms-oil destructors in an open system. Applied Biochemistry and Microbiology 2001. Vol.37. No.4. P.413-417. (russian)

[2] E.R. Fayzulina. Biological methods for the restoration of oil-contaminated soils. News of NAS RK. Biological series. 2010. No.2. P.47-52. (russian)

[3] K.Sh. Faizov. Soils of the Republic of Kazakhstan. Almaty. 2001. P.328

[4] A.S. Saparov, K.Sh. Faizov, I.K. Asanbaev. Soil-ecological condition of the Caspian oil and gas region and ways to improve them. Almaty. 2006. P.148. (russian)

[5] Workshop on microbiology. Ed. Egorova N.S. Moscow: Publishing house of Moscow University. 1976. 307p. (russian)

[6] F. Gerhardt. Methods of General Bacteriology. Moscow: World. 1983. Vol.1. 536p. (russian) 
FIELD TESTING OF IMMOBILIZED OIL-DEGRADING MICROORGANISMS IN THE ZHANATALAP FIELD ... 142-150

[7] V.I. Sokolov, M.A. Kolbin. Liquid chromatography of petroleum products: Moscow: Chemistry. 1984. P.139. (russian)

[8] A.Sh. Galstyan, T.T. Vardanyan. The study of the biological activity of peat. Izvestiya AN Arm. SSR. Series biol. sciences. 1960. Vol.13. No.2. P.77-84. (russian)

[9] T.A. Shcherbakova. Enzymatic activity of soils and transformation of organic matter. Minsk: NiT. 1983. P.222.

[10] D.G. Zvyagintsev. Biological activity of soils and scales for assessing some of its indicators. Soil science. 1978. No.6. P.48-54. (russian)

[11] J. Holeta. The determinant of the bacteria Bergee. Per. from English: Vol.2. Moscow: Mir. 1997. P.432. (russian)

[12] L.V. Lysak, T.G. Dobrovolskaya, I.N. Skvortsova. Methods for assessing the bacterial diversity of soils and the identification of soil bacteria. Moscow: MAX Press. 2003. P.120. (russian)

[13] Environmental monitoring: a teaching tool. under the editorship of T.Ya. Ashihmina. Moscow: Academic Project. 2006. P.416. (russian) 